\title{
University
}

Christeson, G.L., Gulick, S.P.S., Morgan, J.V., Gebhardt, C., Kring, D.A., Le Ber, E., Lofi, J., Nixon, C., Poelchau, M., Rae, A.S.P., Rebolledo-Vieyra, M., Riller, U., Schmitt, D.R., Wittmann, A., Bralower, T.J., Chenot, E., Claeys, P., Cockell, C.S., Coolen, M.J.L., Ferrière, L., Green, S., Goto, K., Jones, H., Lowery, C.M., Mellett, C., Ocampo-Torres, R., Perez-Cruz, L., Pickersgill, A.E., Rasmussen, C., Sato, H., Smit, J., Tikoo, S.M., Tomioka, N., Urrutia-Fucugauchi, J., Whalen, M.T., Xiao, L., and Yamaguchi, K.E. (2018) Extraordinary rocks from the peak ring of the Chicxulub impact crater: P-wave velocity, density, and porosity measurements from IODP/ICDP Expedition 364. Earth and Planetary Science Letters, 495, pp. 111.

There may be differences between this version and the published version. You are advised to consult the publisher's version if you wish to cite from it.

http://eprints.gla.ac.uk/163984/

Deposited on: 20 July 2018

Enlighten - Research publications by members of the University of Glasgow http://eprints.gla.ac.uk 


\section{Extraordinary Rocks from the Peak Ring of the Chicxulub Impact Crater: P-Wave Velocity, Density, and Porosity Measurements from IODP/ICDP Expedition 364}

\section{G.L. Christeson ${ }^{1}$, S.P.S. Gulick ${ }^{1,2}$, J.V. Morgan $^{3}$, C. Gebhardt ${ }^{4}$, D.A. Kring ${ }^{5}$,}

E. Le Ber ${ }^{6}$, J. Lofi ${ }^{7}$, C. Nixon ${ }^{8}$, M. Poelchau', A.S.P. Rae', M. RebolledoVieyra $^{10}$, U. Riller ${ }^{11}$, D.R. Schmitt ${ }^{8,12}$, A. Wittmann ${ }^{13}$, T.J. Bralower ${ }^{14}$, E. Chenot $^{15}$, P. Claeys ${ }^{16}$, C.S. Cockell ${ }^{17}$, M.J.L. Coolen ${ }^{18}$, L. Ferrière ${ }^{19}$, S. Green $^{20}$, K. Goto ${ }^{21}$, H. Jones ${ }^{14}$, C.M. Lowery ${ }^{1}$, C. Mellett ${ }^{22}$, R. OcampoTorres $^{23}$, L. Perez-Cruz ${ }^{24}$, A.E. Pickersgill ${ }^{25,26}$, C. Rasmussen ${ }^{27,28}$, H. Sato ${ }^{29,30}$, J. Smit $^{31}$, S.M. Tikoo ${ }^{32}$, N. Tomioka ${ }^{33}$, J. Urrutia-Fucugauchi' ${ }^{24}$, M.T. Whalen $^{34}$, L. Xiao ${ }^{35}$, and K.E. Yamaguchi ${ }^{36,37}$

${ }^{1}$ University of Texas Institute for Geophysics, Jackson School of Geosciences, Austin, USA

${ }^{2}$ Department of Geological Sciences, Jackson School of Geosciences, Austin, USA

${ }^{3}$ Department of Earth Science and Engineering, Imperial College, London, UK

${ }^{4}$ Alfred Wegener Institute Helmholtz Centre of Polar and Marine Research, Bremerhaven, Germany

${ }^{5}$ Lunar and Planetary Institute, Houston, USA

${ }^{6}$ Department of Geology, University of Leicester, UK

${ }^{7}$ Géosciences Montpellier, Université de Montpellier, France

${ }^{8}$ Department of Physics, University of Alberta, Canada

${ }^{9}$ Department of Geology, University of Freiburg, Germany

${ }^{10}$ SM 312, Mza 7, Chipre 5, Resid. Isla Azul, Cancun, Quintana Roo, Mexico

${ }^{11}$ Institut für Geologie, Universität Hamburg, Germany

${ }^{12}$ Now at Department of Earth, Atmospheric, and Planetary Sciences, Purdue University, USA

${ }^{13}$ Eyring Materials Center, Arizona State University, Tempe, USA

${ }^{14}$ Department of Geosciences, Pennsylvania State University, University Park, USA

${ }^{15}$ Biogéosciences Laboratory, Université de Bourgogne-Franche Comté, France

${ }^{16}$ Analytical, Environmental and Geo-Chemistry, Vrije Universiteit Brussel, Brussels, Belgium

${ }^{17}$ School of Physics and Astronomy, University of Edinburgh, UK

${ }^{18}$ Department of Chemistry, WA-Organic and Isotope Geochemistry Centre (WA-OIGC), Curtin University, Bentley, Australia

${ }^{19}$ Natural History Museum, Vienna, Austria

${ }^{20}$ British Geological Survey, Edinburgh, UK

${ }^{21}$ International Research Institute of Disaster Science, Tohoku University, Sendai, Japan

${ }^{22}$ United Kingdom Hydrographic Office, Taunton, UK 
${ }^{23}$ Groupe de Physico-Chimie de l'Atmosphère, L'Institut de Chimie et Procédés pour l'Énergie, l'Environnement et la Santé (ICPEES), Université de Strasbourg, France

${ }^{24}$ Instituto de Geofísica, Universidad Nacional Autónoma De México, Ciudad de México, México

${ }^{25}$ School of Geographical and Earth Sciences, University of Glasgow, UK

${ }^{26}$ Argon Isotope Facility, Scottish Universities Environmental Research Centre (SUERC), East Kilbride, UK

${ }^{27}$ Department of Geology and Geophysics, University of Utah, Salt Lake City, USA

${ }^{28}$ Now at University of Texas Institute for Geophysics, Jackson School of Geosciences, Austin, USA

${ }^{29}$ Japan Agency for Marine-Earth Science and Technology, Kanagawa, Japan

${ }^{30}$ Now at Ocean Resources Research Center for Next Generation, Chiba Institute of Technology, Chiba, Japan

${ }^{31}$ Faculty of Earth and Life Sciences (FALW), Vrije Universiteit Amsterdam, Netherlands

${ }^{32}$ Earth and Planetary Sceinces, Rutgers University New Brunswick, USA

${ }^{33}$ Kochi Institute for Core Sample Research, Japan Agency for Marine-Earth Science and Technology, Kochi, Japan

${ }^{34}$ Department of Geosciences, University of Alaska Fairbanks, USA

${ }^{35}$ School of Earth Sciences, Planetary Science Institute, China University of Geosciences (Wuhan), China

${ }^{36}$ Department of Chemistry, Toho University, Chiba, Japan

${ }^{37}$ NASA Astrobiology Institute

Corresponding author:

Gail L Christeson

University of Texas Institute for Geophysics

Jackson School of Geosciences

J.J. Pickle Research Campus, Mail Code R2200

10100 Burnet Rd, Austin, Texas 78758

(512)471-0463

gail@ig.utexas.edu

1

2 Revised for EPSL April 4, 2018 


\section{Highlights}

- Chicxulub peak-ring rocks have low velocities and densities, and high porosities.

- Physical property values indicate considerable damage of granitoid peak-ring rocks.

- Suevite flowed downslope during and after peak-ring formation

Abstract. Joint International Ocean Discovery Program and International Continental Scientific Drilling Program Expedition 364 drilled into the peak ring of the Chicxulub impact crater. We present P-wave velocity, density, and porosity measurements from Hole M0077A that reveal unusual physical properties of the peak-ring rocks. Across the boundary between post-impact sedimentary rock and suevite (impact melt-bearing breccia) we measure a sharp decrease in velocity and density, and an increase in porosity. Velocity, density, and porosity values for the suevite are $2900-3700 \mathrm{~m} / \mathrm{s}, 2.06-2.37 \mathrm{~g} / \mathrm{cm}^{3}$, and 20-35\%, respectively. The thin $(25 \mathrm{~m})$ impact melt rock unit below the suevite has velocity measurements of $3650-4350 \mathrm{~m} / \mathrm{s}$, density measurements of $2.26-2.37 \mathrm{~g} / \mathrm{cm}^{3}$, and porosity measurements of $19-22 \%$. We associate the low velocity, low density, and high porosity of suevite and impact melt rock with rapid emplacement, hydrothermal alteration products, and observations of pore space, vugs, and vesicles. The uplifted granitic peak ring materials have values of $4000-4200 \mathrm{~m} / \mathrm{s}, 2.39-2.44 \mathrm{~g} / \mathrm{cm}^{3}$, and $8-13 \%$ for velocity, density, and porosity, respectively; these values differ significantly from typical unaltered granite which has higher velocity and density, and lower porosity. The majority of Hole M0077A peak-ring velocity, density, and porosity measurements indicate considerable rock damage, and are consistent with numerical model predictions for peak-ring formation where the lithologies present within the peak ring represent some of the most shocked and damaged rocks in an impact basin. We integrate our results with previous seismic datasets to map the suevite near the borehole. We map suevite below the Paleogene sedimentary rock in the annular trough, on the peak ring, and in the central basin, implying that, post impact, suevite covered the entire floor of the impact basin. Suevite thickness is $100-165 \mathrm{~m}$ on the top of the peak ring but $200 \mathrm{~m}$ in 
30 the central basin, suggesting that suevite flowed downslope from the collapsing central uplift

31 during and after peak-ring formation, accumulating preferentially within the central basin.

32 Keywords. Chicxulub, peak ring, physical properties, impact crater

\section{Introduction}

Present in the two largest classes of impact craters, peak-ring craters and multi-ring basins,

35 peak rings are interpreted to develop from gravitational collapse of a central peak, and exhibit a

36 circular ring of elevated topography interior of the crater rim [e.g., Grieve et al., 1981; Morgan

37 et al., 2016]. Surface topography can be observed for craters on the Moon and other rocky

38 planets, but on Earth craters can also be characterized at depth by boreholes and geophysical

39 studies. The Chicxulub impact crater is the only known terrestrial crater that preserves an

40 unequivocal peak ring [e.g., Morgan et al., 1997; Morgan et al., 2000], and can provide

41 important information related to peak-ring formation with implication for how impacts act as a

42 geologic process on planetary surfaces.

43 The Chicxulub peak ring has been imaged by a grid of seismic reflection profiles (Figure 1),

44 which constrain a morphological feature that rises $\sim 0.2-0.6 \mathrm{~km}$ above the floor of the central

45 basin and annular trough and is overlain by $\sim 0.6-1.0 \mathrm{~km}$ of post-impact sedimentary rock

46 [Morgan et al., 1997; Gulick et al., 2008; Gulick et al., 2013] (Figure 2b). Tomographic velocity

47 images associate the uppermost $0.1-0.2 \mathrm{~km}$ of the peak ring with low seismic velocities (Figure

48 2), which were interpreted as a thin layer of highly porous allogenic impact breccias [Morgan et

$49 a l ., 2011]$. Velocities $0.5-2.5 \mathrm{~km}$ beneath the peak-ring surface are reduced compared to adjacent

50 material in the annular trough and central basin [Morgan et al., 2000; Morgan et al., 2002], and

51 were interpreted as highly-fractured basement rocks [Morgan et al., 2000], as predicted by

52 numerical simulations of peak-ring formation [e.g., Collins et al., 2008].

53 The International Ocean Discovery Program and International Continental Scientific Drilling

54 Program (IODP/ICDP) Expedition 364 drilled and cored the Chicxulub peak ring and overlying

55 post-impact sedimentary rock from depths 505.7-1334.7 $\mathrm{m}$ below the seafloor (mbsf) [Morgan et 
al., 2017]. Hole M0077A (Figure 1) provides the ground-truth information calibrating our

57 geophysical data and interpretations. Here we report the first P-wave velocity, density, and

58 porosity measurements of the Chicxulub peak ring at scales ranging from centimeters to meters.

59 We combine these results with existing geophysical data to gain insight into deposition of suevite

60 (impact melt-bearing breccia [Stöffler and Grieve, 2007]) and impact melt rock (crystalline rock

61 solidified from impact melt [Stöffler and Grieve, 2007]), and into the physical state of the peak-

62 ring rocks.

\section{2. Datasets}

\section{$64 \quad$ 2.1. Surface Seismic Surveys}

65 Deep-penetration seismic reflection surveys that image the Chicxulub impact crater were 66 acquired in 1996 [Morgan et al., 1997] and 2005 [Gulick et al., 2008]. These data include

67 regional profiles and a grid over the northwest peak-ring region. Air gun shots fired for these two

68 surveys were also recorded by ocean bottom and land seismometers (Figure 1). The seismic

69 reflection images are most recently summarized in Gulick et al. [2013]. Morgan et al. [2011]

70 used wide-angle seismic data recorded on the 6-km seismic reflection hydrophone cable

71 (streamer) to produce high-resolution full-waveform inversion (FWI) velocity models of the

72 shallow crust. The surface seismic data predicted the top of the peak ring at Hole M0077A at 650

$73 \operatorname{mbsf}($ Figure 2b).

74 In this study we focus on comparisons of Expedition 364 results with seismic reflection

75 images and FWI velocity models. Vertical resolution in seismic reflection images (Figure 2b) at

76 the top of the peak ring is $\sim 35-40 \mathrm{~m}$ (one quarter of the $\sim 150-\mathrm{m}$ seismic wavelength [e.g.,

77 Yilmaz, 1987] for a frequency of $20 \mathrm{~Hz}$ and velocity of $3000 \mathrm{~m} / \mathrm{s}$, which is the average P-wave

78 velocity in the suevite). Spatial resolution for FWI velocity models at the top of the peak ring

79 (Figure 2a) is $\sim 150-\mathrm{m}$ (half the $~ 300-\mathrm{m}$ seismic wavelength [Virieux and Operto, 2009] for the

80 highest FWI frequency of $10 \mathrm{~Hz}$ and velocity of $3000 \mathrm{~m} / \mathrm{s}$ [Morgan et al., 2011]). 


\subsection{Core Measurements}

P-wave and Moisture and Density (MAD) measurements were made on sample plugs with

83 average volumes of $\sim 6 \mathrm{~cm}^{3}$ at $\sim 1 \mathrm{~m}$ spacing throughout all the cores. P-wave velocities were

84 measured using a source frequency of $250 \mathrm{kHz}$ (wavelength of $\sim 1 \mathrm{~cm}$ at $3000 \mathrm{~m} / \mathrm{s}$ ), and have an

85 estimated uncertainty of $\sim 125 \mathrm{~m} / \mathrm{s}$ based on the standard deviation between repeat measurements

86 on a subset of samples. MAD procedures included obtaining wet and dry sample weights and dry

87 sample volume; these values allowed computation of bulk density and porosity. Weights and

88 volumes were obtained to a precision of $0.0001 \mathrm{~g}$ and $0.04 \mathrm{~cm}^{3}$, respectively, which result in

89 estimated uncertainties for bulk densities of $\sim 0.006 \mathrm{~g} / \mathrm{cm}^{3}$ and porosities of $<0.1 \%$. Gamma ray

90 attenuation bulk density measurements were acquired at 2-cm intervals on the whole-round cores

91 using a Geotek multi-sensor core logger; uncertainty of these values is $\sim 0.075 \mathrm{~g} / \mathrm{cm}^{3}$ based on

92 the standard deviation between repeat measurements on a subset of samples. Depths are reported

93 in meters below sea floor (mbsf). Morgan et al. [2017] provide additional details on the core

94 measurements.

\subsection{Downhole Velocity Measurements}

P-wave sonic velocities were measured in open hole at $5-\mathrm{cm}$ spacing with a source frequency of $6 \mathrm{kHz}$ (wavelength of $\sim 50 \mathrm{~cm}$ at $3000 \mathrm{~m} / \mathrm{s}$ ) throughout the entire drill hole using a wireline logging tool. Uncertainties for the downhole sonic velocities are estimated to be $\sim 250 \mathrm{~m} / \mathrm{s}$ based on uncertainties in travel time picks. Vertical seismic profile (VSP) measurements were recorded at 1.25-5.0 m spacing throughout the drill hole using a 30/30 cubic inch Sercel Mini GI air gun source (wavelength of $\sim 30 \mathrm{~m}$ for a frequency of $100 \mathrm{~Hz}$ and velocity of $3000 \mathrm{~m} / \mathrm{s}$ ). P-wave velocities from the VSP were calculated using procedures developed in Schmitt et al. [2007], and have an estimated uncertainty of $\sim 85 \mathrm{~m} / \mathrm{s}$. Downhole depths were calculated from wireline distance, and have been corrected to mbsf for consistency. Additional details on the downhole velocity measurements are provided in Morgan et al. [2017]. 


\section{Results}

\subsection{Hole M0077A Physical Properties}

Figure 3 summarizes velocity, porosity, and density measurements for the cored interval of

110 Table 1. Porosity trends are typically observed to be inversely correlated with velocity, while 111 density trends are positively correlated with velocity. Discrete sample velocities at most depths

112 are consistently slightly higher than downhole log and VSP velocities. This is likely in part

113 because lower-frequency log and VSP measurements sample fractures at a larger scale (seismic

114 wavelengths of $\sim 50 \mathrm{~cm}$ and $30 \mathrm{~m}$, respectively) than the discrete samples (seismic wavelength of

$115 \sim 1 \mathrm{~cm}$ ), and discrete samples are specifically selected at positions where the core is relatively

116 intact. Overall, changes in velocity with depth are consistent across the three different velocity

117 measurements (Figure 3c).

118 In the Paleogene $(\mathrm{Pg})$ sedimentary rock, marlstone/limestone-dominated subunits $1 \mathrm{~A}-1 \mathrm{D}$

119 have lower velocities and densities, and higher porosities, than the underlying limestone-

120 dominated subunits 1E-1F (Figure 3 and Table 1). With increasing depth, velocities increase 121 from $2500-3000 \mathrm{~m} / \mathrm{s}$ to $3000-4000 \mathrm{~m} / \mathrm{s}$ (Figure 3c), porosities decrease from $25-35 \%$ to $10-15 \%$

122 (Figure 3d), and bulk densities increase from $\sim 2.0 \mathrm{~g} / \mathrm{cm}^{3}$ to $2.5 \mathrm{~g} / \mathrm{cm}^{3}$ (Figure $3 \mathrm{e}$ ). A core 123 photograph of representative limestone from unit $1 \mathrm{~F}$, near the base of the Pg sedimentary rock, is 124 displayed in Figure 4a. There is a remarkable decrease in velocities and bulk densities, and a 125 prominent increase in porosities, at the boundary between Pg sedimentary rock (unit 1) and 126 suevite (unit 2) at $~ 617$ mbsf.

127 The suevite (unit 2, Figures $4 b-d$ ) consists of clasts of impact melt, sedimentary rock, and 128 basement lithologies, embedded in a fine-grained dominantly calcitic matrix, with maximum 129 clast size increasing with depth from $0.2-1.0 \mathrm{~cm}$ to $>20-25 \mathrm{~cm}$ [Morgan et al., 2017]. Suevite 130 discrete sample measurements of velocities, porosities, and densities display an increase in 131 variability at depths $>678 \mathrm{mbsf}$ (Figure 3 ). Velocities are $\sim 2800-3300 \mathrm{~m} / \mathrm{s}$ in the suevite from $132 \sim 617$ to 706 mbsf, where a sharp increase in borehole sonic P-wave values is observed to 
133 average velocities of $\sim 3700 \mathrm{~m} / \mathrm{s}$ (Figure 3c). This velocity increase correlates at $706 \mathrm{mbsf}$ with

134 the first observation of significant impact melt rock as up to 60-cm-thick intercalations in 135 suevite, and with an increase in average maximum clast size from $\sim 5 \mathrm{~cm}$ to $\sim 13 \mathrm{~cm}$ in its host 136 suevite [Morgan et al., 2017]. This velocity increase is also close to the boundary between 137 subunits $2 \mathrm{~B}$ and $2 \mathrm{C}$ at $713 \mathrm{mbsf}$, which is characterized by a change in suevite color from green, 138 gray, and black in subunit 2B (Figure 4c) to brown in subunit 2C (Figure 4d). Suevite porosities 139 decrease from $\sim 35 \%$ at 617 mbsf to $\sim 31 \%$ at 706 mbsf, with a sharp decrease to values of $\sim 20 \%$

140 in the lowermost part (706-722 mbsf) of the unit. Suevite bulk densities increase with depth from $1412.0-2.1 \mathrm{~g} / \mathrm{cm}^{3}$ in unit $2 \mathrm{~A}(617-665 \mathrm{mbsf})$ to $2.3-2.4 \mathrm{~g} / \mathrm{cm}^{3}$ in unit $2 \mathrm{C}(713-722 \mathrm{mbsf})$. Near the 142 base of unit 2B from 689-706 mbsf a decrease in sample and logging velocities (from 3100$1433300 \mathrm{~m} / \mathrm{s}$ to $\sim 2800-2850 \mathrm{~m} / \mathrm{s}$ ), a decrease in densities (from $\sim 2.2 \mathrm{~g} / \mathrm{cm}^{3}$ to $\sim 2.15 \mathrm{~g} / \mathrm{cm}^{3}$ ), and an 144 increase in porosities (from $\sim 26 \%$ to $\sim 31 \%$ ) is observed for the suevite (Figure 3). Additional 145 analyses will be required to explain these observations as our visual inspection of the core 146 provides no clear reason for the change in physical properties from 689-706 mbsf.

147 Impact melt rock (Figure 4e and Table 1, units 3A-3B) velocities (3600-4400 m/s), densities $148 \quad\left(2.29-2.37 \mathrm{~g} / \mathrm{cm}^{3}\right)$, and porosities (19-22\%) are similar to the suevite at 706-722 mbsf.

149 Crystalline basement unit 4 is not divided into subunits by Morgan et al. [2017]. The dominant 150 lithology is granitoid, but significant suevite, impact melt rock, and dolerite rock types are also 151 identified, and physical property values display increased variability at depths 1251-1316 mbsf 152 where suevite and impact melt rock are prevalent (Figure 3). Velocities in unit 4 are typically $1534000-4200 \mathrm{~m} / \mathrm{s}$, but higher velocities averaging $4821 \mathrm{~m} / \mathrm{s}$ are observed for discrete sample 154 measurements of dolerite (Figure 3 and Table 1). Densities are significantly lower (2.28-2.33 $155 \mathrm{~g} / \mathrm{cm}^{3}$ vs. $\left.2.40-2.58 \mathrm{~g} / \mathrm{cm}^{3}\right)$ and porosities significantly higher $(15-19 \%$ vs. $10 \%)$ for suevite and 156 impact melt rock compared to granitoid and dolerite rocks (Figure 3 and Table 1). Compared to 157 units 2 and 3, the suevite and impact melt rock within unit 4 have higher velocities and densities, 158 and lower porosities (Figure 3 and Table 1). 


\subsection{Integration of Expedition 364 Data with Surface Seismic Datasets}

Figure 5 compares the downhole sonic log and VSP with seismic reflection images from 161 three profiles, all within $200 \mathrm{~m}$ of Hole M0077A (Figure 1c); we converted the seismic reflection 162 data to depth using the 1D VSP velocity profile at the drill site. The different methods sample the 163 subsurface at different seismic wavelengths: $\sim 50 \mathrm{~cm}, \sim 30 \mathrm{~m}$, and $\sim 150 \mathrm{~m}$ at peak ring depths for 164 downhole sonic, VSP, and seismic reflection, respectively. The Pg sedimentary rock is 165 associated with a subhorizontal layered reflective sequence [e.g., Morgan et al., 1997]. A 500$166 \mathrm{~m} / \mathrm{s}$ increase in VSP velocities at $\sim 300 \mathrm{~m}$ depth correlates with a large amplitude reflection on 167 the seismic images, but is above the depths at which core was recovered. The sharp changes in 168 downhole sonic velocities at the top (617 mbsf) and base (706 mbsf) of suevite (Figure 5a) 169 correspond to the top (580-625 $\mathrm{m}$ depth) and base (650-690 $\mathrm{m}$ depth) of high-amplitude low170 frequency reflectors imaged on the seismic reflection profiles (Figure 5b-d). Short, dipping, low171 frequency reflectors are imaged in the profiles at depths of $725-1100 \mathrm{~m}$, likely associated with

172 the impact melt rock and fractured basement. Reflectivity is largely incoherent at depths $>1100$ $173 \mathrm{~m}$ in Figure 5b-d.

174 Figure 2 places Hole M0077A measurements in the regional context. A 100-200 m thick 175 layer of low-velocity ( $\sim 3000-3200 \mathrm{~m} / \mathrm{s}$, compared with $>3600 \mathrm{~m} / \mathrm{s}$ above and below) rocks lies at 176 the top of the peak ring in FWI tomographic images [Morgan et al., 2011]. The top of the low177 velocity zone correlates with the top of the package of low-frequency reflectors imaged on the 178 seismic reflection data, and tracks the interpreted location of the K-Pg boundary from the top of 179 the peak ring into the annular trough. At Hole M0077A the base of the low-velocity zone in 180 downhole sonic data correlates with the base of the low-frequency reflector package (Figure 5). 181 However, Morgan et al. [2011] note that the velocity increase at the base of the low-velocity 182 zone is associated with a deeper intermittent low-frequency reflector. We present both 183 interpretations in Figure 2.

184 Figure 6 displays the broader context of the seismic reflection profiles of Figure 5. We use 185 the low-velocity zone in the high-resolution FWI velocity models of Morgan et al. [2011; e.g., 
186 Figure 2], where available, as a guide for mapping the suevite. Average suevite thickness is $\sim 130$

$187 \mathrm{~m}$ in the annular trough, $\sim 200 \mathrm{~m}$ in the central basin, and $\sim 100$ or $\sim 165 \mathrm{~m}$ on the peak ring for

188 the two different interpretations presented in Figure 5. Based on past mapping [Gulick et al.,

189 2013] and onshore boreholes, we interpret the top of the suevite as the K-Pg boundary layer

190 equivalent within the crater; the suevite unit overlies slump blocks and impact melt rock in the

191 annular trough and overlies impact melt rock in the central basin (Figure 6).

\section{4. Discussion}

\section{4.1. Physical Property Changes}

194 Figure 3 illustrates that there is considerable variability in velocity, density, and porosity 195 measurements at Hole M0077A. Factors that might affect the physical properties include 196 composition, fractures (i.e., abundance, connectivity, open, filled with secondary minerals), 197 depositional rate, and intensity of shock. For a given rock type, we expect P-wave velocity to 198 increase, density to increase, and porosity to decrease with increasing depth beneath the seafloor 199 as cracks within the rock close with increasing pressure [e.g., see review in Schmitt, 2015].

200 Laboratory measurements of sedimentary rock such as limestone yield lower velocity and 201 density values than those of crystalline rock such as granite [e.g., Birch, 1960]. The addition of 202 clay, which could form as an alteration product from fluids associated with a post-impact 203 hydrothermal system, will decrease P-wave velocities; experiments in sandstone show that a very 204 small amount of clay (1\%) will significantly reduce the elastic modulus [Han et al., 1986]. Clays 205 typically have lower densities than the material they replace, and thus alteration should also 206 decrease bulk density. Adding cracks to a rock will decrease velocity and density, and increase 207 porosity [Walsh, 1965; Toksöz et al., 1976]. Rapid sedimentary rock deposition is associated 208 with preservation of high porosities if pore fluid pressure is preserved [Bloch et al., 2002]. 209 Experiments show that shock, especially at high temperatures, will reduce the density of quartz 210 [Langenhorst and Deutsch, 1994]. We will consider these factors when discussing the physical 211 property changes observed at the Chicxulub peak ring. 


\subsection{Low-Velocity Zone}

213 A low-velocity zone is observed in downhole sonic, VSP, and FWI velocity measurements

214 (Figure 5a). Spatial resolution is $\sim 80-\mathrm{cm}$ for sonic, $\sim 30-\mathrm{m}$ for VSP, and $\sim 150 \mathrm{~m}$ for FWI. As a

215 consequence of resolution differences, the top and bottom of the FWI low-velocity zone is

216 relatively smooth in comparison to the sharp boundaries in the sonic measurements (the VSP

217 measurements are at a scale between sonic and FWI).

218 The top of the low-velocity zone in FWI data near Hole M0077A is at $~ 630$ mbsf, which is

$219 \sim 13 \mathrm{~m}$ deeper than the top of the low-velocity zone at $617 \mathrm{mbsf}$ observed in downhole sonic

220 velocity measurements (Figure 5a). This discrepancy is likely the result of seismic anisotropy.

221 The refracted energy used to construct the FWI velocity model primarily traveled in a horizontal

222 direction, which is typically faster than velocities in the vertical direction in layered sediments.

223 This anisotropy will result in faster velocities above the low-velocity zone in FWI velocity

224 models, and a greater depth to the low-velocity zone.

225 The base of the low-velocity zone in FWI data near Hole M0077A is at $~ 800$ mbsf,

226 corresponding to intermittent low-frequency reflectivity imaged in surface seismic reflection

227 data, although this depth is also probably overestimated due to anisotropy (Figures 2 and 5; note

228 that Figure 2 is depth below sea level and needs to be shifted up $19.8 \mathrm{~m}$ to compare with depth

229 below seafloor plotted in Figure 5). This depth results in an estimated thickness of $\sim 170 \mathrm{~m}$ in the

230 FWI model, which is considerably greater than the thickness of $\sim 89 \mathrm{~m}$ observed in the sonic

231 velocity log. The FWI velocity model, however, is band-limited, which means that an abrupt-

232 edged low-velocity layer will be spread over a larger distance which can account for some of the

233 thickness differences.

234 Alternatively, we can use the seismic reflection imaging as a guide for the low-velocity zone.

235 Amplitude changes in seismic reflection data are caused by changes in velocity and density. The

236 top of the low-velocity zone correlates with sharp decreases in both velocity and density (Figure

237 3), and correlates with the top of a high-amplitude low-frequency reflector package in seismic

238 reflection images (Figure 5). The base of the low-velocity zone in downhole sonic measurements 
239 is associated with a sharp increase in velocity, and a more gradual increase in density, and

240 correlates with the base of the high-amplitude low-frequency reflector package. If we use this

241 interpretation (dashed lines in Figure 5b-d), then the low-velocity zone thickness is $\sim 75-90 \mathrm{~m}$,

242 which is consistent with the downhole sonic measurements. We present both interpretations for

243 low-velocity zone thickness in Figure 6, and plan future work on FWI modeling to better resolve

244 the low-velocity zone thickness throughout the crater.

\section{4.3. Onshore Wells}

246 We can compare Hole M0077A physical properties with nearby ICDP well Yaxcopoil-1

247 (Yax-1) where velocity, porosity, and density measurements were made on discrete samples

248 [Vermeesch and Morgan, 2004; Mayr et al., 2008; Elbra and Pesonen, 2011], and with well Y6

249 where velocity measurements were made on sparse samples [Morgan et al., 2000; Vermeesch,

250 2006] (see Figure 1 for well locations). Stratigraphy at Yax-1 consists of Cenozoic sedimentary

251 rock (795 m thick), suevite and brecciated impact melt rock (100 m thick), and Cretaceous

252 sedimentary rock megablocks (616 m thick) [Kring et al., 2004; Stöffler et al., 2004], while Y6

253 consists of Pg sedimentary rock ( 1200 m thick), suevite ( 70 m thick), and impact melt rock

254 ( 385 m thick) [Hildebrand et al., 1991; Sharpton et al., 1996; Kring, 2005]. The equivalent of

255 the Yax-1 Cretaceous megablocks are interpreted to be down-dropped to $>3.5 \mathrm{~km}$ depth at Hole

256 M0077A, over two km below the bottom of the borehole [Gulick et al., 2013]. Across the

257 boundary from Pg sedimentary rock to suevite at Yax-1, velocities decrease from 3700-4100

$258 \mathrm{~m} / \mathrm{s}$ to $\sim 2800-3500 \mathrm{~m} / \mathrm{s}$, porosities increase from $\sim 10-15 \%$ to $\sim 18-37 \%$, and bulk densities

259 decrease from $\sim 2.4-2.55 \mathrm{~g} / \mathrm{cm}^{3}$ to $\sim 2.0-2.35 \mathrm{~g} / \mathrm{cm}^{3}$ [Mayr et al., 2008; Elbra and Pesonen, 2011$]$.

260 Physical properties are relatively constant within units 1-5 (upper $90 \mathrm{~m}$ ) of the Yax-1 suevite, but 261 change abruptly in "Lower Suevite" unit 6 (lower 10 m, where lithic components are dominated 262 by carbonates) to velocities of 4.0-6.5 km/s, porosities of $1-11 \%$, and densities of $2.35-2.6 \mathrm{~g} / \mathrm{cm}^{3}$ 263 [Mayr et al., 2008; Elbra and Pesonen, 2011]. At Y6 velocities average $4100 \mathrm{~m} / \mathrm{s}, 3900 \mathrm{~m} / \mathrm{s}$, and 
$2645800 \mathrm{~m} / \mathrm{s}$ in the lowermost Pg sedimentary rock, suevite, and impact melt rock, respectively

265 [Morgan et al., 2000; Vermeesch, 2006].

\subsection{Suevite}

267 The boundary between Pg sedimentary rock and suevite at 617 mbsf in Hole M0077A is associated with a sharp decrease in downhole sonic log velocity, an increase in porosity, a

269 decrease in bulk density, the top of the low-frequency reflector package on seismic reflection 270 profiles, and the top of a low-velocity layer in FWI images (Figures 2, 3, and 5). Similar

271 velocity, porosity, and density changes at the top of the suevite are observed at onshore well 272 Yax-1 [Mayr et al., 2008; Elbra and Pesonen, 2011] located $\sim 82 \mathrm{~km}$ to the south (Figure 1), 273 suggesting that this boundary might be fairly uniform in physical properties throughout the 274 impact basin. An increase in variability in velocity, porosity, and density values at depths $>678$ mbsf in Hole M0077A (Figure 3) is likely a result of maximum clast size increasing to $>5 \mathrm{~cm}$,

276 resulting in sample plugs that may consist entirely of either matrix or a single clast (Figure 4c).

277 The base of the suevite section, identified from core data at $722 \mathrm{mbsf}$ in Hole M0077A, is not 278 associated with a clear change in physical properties; instead, the major change in physical 279 properties (increase in velocity and density, and a decrease in porosity) is observed at $\sim 706$ mbsf 280 (Figure 3) where coherent bodies of impact melt rock $>10 \mathrm{~cm}$ thick first occur. The physical 281 properties (Figure 3) of the lowest part of the suevite (706-722 mbsf) in Hole M0077A (Figure $2824 \mathrm{~d}$ ) are similar to those of the underlying impact melt rock units 3A and 3B at 722-747 mbsf 283 (Figure 4e), which suggests that values are dominated by the melt clasts which range in size from 284 a few $\mathrm{mm}$ to $>10 \mathrm{~cm}$ at depths 706-722 mbsf [Morgan et al., 2017].

285 Suevite from depths 617 to 706 mbsf is characterized by lower velocities and densities, and 286 higher porosities, than the overlying Pg sedimentary rock and underlying suevite and impact melt 287 rock (Figure 3). Decreased P-wave velocity in a material can be caused by the addition of cracks 288 [e.g., Walsh, 1965; Toksöz et al., 1976] or preserved porosity due to rapid emplacement [e.g., 289 Bloch et al., 2002]. However, fractures are not commonly observed in suevite at Hole M0077A 
290 and no significant overpressure was observed [Morgan et al., 2017]. Alteration to clay can also

291 decrease velocities, and suevite in this interval is dominated by rounded, shard-shaped impact

292 melt particles that were produced from highly vesicular, glassy impact melt that is now

293 pervasively altered to phyllosilicates. Some pore space has been filled with secondary zeolites

294 and calcite. Also observed are dark gray subvertical pipes or patches interpreted as possible

295 degassing or dewatering pipes, and vesicular melt rock fragments where vesicles are either

296 empty or filled with carbonate and/or matrix material. Alteration products and gas vesicles were

297 also documented in suevite at onshore borehole Yax-1, where analyses show that early $\mathrm{Ca}-\mathrm{Na}-\mathrm{K}$

298 metasomatism is followed by abundant phyllosilicate clay replacement [Hecht et al., 2004; Kring

299 et al., 2004; Zürcher and Kring, 2004]. Initial analyses and visual inspection at Hole M0077A

300 indicate that most of the former glassy melt has been devitrified to clay minerals within the

301 suevite, while glass in the overlying Paleogene sedimentary rock is either silicified or calcitized

302 with less alteration to clay. We interpret the observed low P-wave velocity and density in the

303 suevite, at depths 617 to $706 \mathrm{mbsf}$, as a function of their richness in alteration products that are

304 preferentially composed of water-rich, high-porosity phyllosilicates/clay minerals and zeolites.

305 High porosities are also consistent with the observations of pore space, vugs and vesiculated

306 clasts of impact melt in the suevite.

307 Wittmann et al. [2007] propose a suevite emplacement model based on petrologic and image

308 analytical methods of well Yax-1 cores that starts with excavation-flow material interacting with

309 the ejecta plume, followed by lateral transport during central uplift collapse, and finalized by

310 collapse of the ejecta plume, fall back of ejecta, and very minor aquatic reworking. There is also

311 evidence in the uppermost units for gravity flows triggered by ocean water invasion or an impact

312 seismic wave [Goto et al., 2004]. We would expect that excavation flow and lateral mass

313 transport would preferentially fill in and smooth the crater floor, with flow downslope during and

314 after peak-ring formation [Kring, 2005]. The later stage of fall back ejecta should drape the

315 lower suevite with relatively constant thickness, with some variability associated with gravity

316 flows. Our mapping of the top and base of the main suevite unit (Figure 6) can help test this 
317 model. In Figure 6a, there are two interpretations for suevite thickness on the peak ring, but with

318 either interpretation the suevite thickens from the peak ring $(\sim 100-160 \mathrm{~m})$ into the central basin

319 ( 200 m); a thicker suevite in the central basin compared to the top of the peak ring is consistent

320 with observations from onshore boreholes S1 and C1, where suevite thickness is $400 \mathrm{~m}$ and

$321 \sim 200 \mathrm{~m}$, respectively [Hildebrand et al., 1991; Kring, 2005]. Figure 6b is more complex, with

322 the suevite either thickening or thinning from the peak ring $(\sim 80-165 \mathrm{~m})$ into the annular trough

$323(\sim 115 \mathrm{~m})$ depending on the interpretation on top of the peak ring. In Figure $6 \mathrm{c}$ there is slight

324 thickening of the suevite from the peak ring $(\sim 110 \mathrm{~m})$ into the annular trough $(\sim 140 \mathrm{~m})$.

325 Regardless of which suevite thickness interpretation is correct on top of the peak ring, our

326 mapping indicates variable suevite thickness which supports a model that includes ground surge

327 and lateral mass transport. The mapping is also consistent with the Kring [2005] model for

328 suevite flowing downslope from a collapsing central uplift during and after peak-ring formation,

329 accumulating preferentially within the central basin (and perhaps also the annular trough). Our

330 mapping implies that, post-impact, suevite covered the entire floor of the impact basin including

331 the annular trough, peak ring, and central basin.

\section{4.5. Impact Melt Rock}

333 Previous studies have interpreted a low-frequency reflector on seismic reflection profiles, 334 imaged largely within the central basin, as the top of an impact melt sheet [Barton et al., 2010;

335 Morgan et al., 2011; Gulick et al., 2013]. This reflector is correlated with an increase to

336 velocities $>5500 \mathrm{~m} / \mathrm{s}$, is mapped at an average depth of $1900 \mathrm{~m}$ throughout the central basin and

337 discontinuously in the annular trough, and is mostly absent beneath the peak ring [Barton et al.,

338 2010; Morgan et al., 2011; Gulick et al., 2013]. The 25-m-thick impact melt rock unit underlying

339 the suevite at Hole M0077A is at 722-747 mbsf, much shallower than the expected top of the

340 coherent melt sheet at $\sim 1900 \mathrm{~m}$. Therefore, it probably represents a thin interval of melt

341 deposited on top of the granitoid peak ring. We do interpret a thicker interval of impact melt rock

342 underlying the suevite within the central basin (Figure 6a). 
Onshore wells C1, S1, and Y6 (Figure 1) encountered 110 to >360-m-thick impact melt rock

344 at the bottom of the boreholes [Hildebrand et al., 1991; Sharpton et al., 1992; Ward et al., 1995;

345 Kring et al., 2004], which is substantially thicker than drilled at Hole M0077A. Discrete sample

346 measurements on the impact melt rock at well Y6 have velocity values of $5800 \mathrm{~m} / \mathrm{s}$ and density

347 values of $2.68 \mathrm{~g} / \mathrm{cm}^{3}$ [Morgan et al., 2000; Vermeesch, 2006], which are considerably higher

348 than the mean values of 3788-4144 m/s (downhole sonic log and discrete samples, Table 1) and

$349 \quad 2.32-2.34 \mathrm{~g} / \mathrm{cm}^{3}$ (MSCL and discrete samples, Table 1) measured for impact melt rock units 3A

350 and 3B at Hole M0077A. Compared to the suevite and impact melt rock at Hole M0077A, and

351 the suevite in well Y6, the Y6 impact melt rock has much less clay, zeolite, and carbonate

352 alteration products [Kring and Boynton, 1992; Schuraytz et al., 1994]. Fracturing is not common

353 in Hole M0077A impact melt rock [Morgan et al., 2017], so the velocity and density differences

354 between Y6 and M0077A melt rock cannot be explained by the effect of cracks on physical

355 properties. However, as in the suevite, alteration products such as smectite, zeolite, silica, and

356 chloritoid/chlorite, and also vesicles are prevalent in Hole M0077A impact melt rock [Morgan et

$357 a l ., 2017]$, and these are the likely cause of the observed low velocity, low density, and high

358 porosity.

\subsection{Peak Ring Rocks}

360 Velocities of 4000-4225 m/s are measured in the granitoid rocks at Hole M0077A (Figure 3

361 and Table 1), which are substantially lower than typical granite velocities of 5400-6000 m/s

362 measured at room temperatures and low pressures [Birch, 1960; Nur and Simmons, 1969; David

363 et al., 1999]. Likewise, densities of 2.39-2.44 g/cm $\mathrm{cm}^{3}$ and porosities of 8-13\% (Figure 3 and Table

364 1) significantly differ from typical granite values of $2.62-2.67 \mathrm{~g} / \mathrm{cm}^{3}$ and $<1 \%$, respectively

365 [Birch, 1960; Nur and Simmons, 1969]. In comparison, samples from an allochthonous 275-m

366 granitic megablock drilled in the annular moat of the Chesapeake Bay impact structure have

367 velocities, densities, and porosities of 5800-6500 m/s, 2.61-2.66 g/ $\mathrm{cm}^{3}$, and $<1 \%$, respectively

368 [Mayr et al., 2009]; these values largely overlap typical granite values [Birch, 1960; Nur and 
Simmons, 1969; David et al., 1999]. Exterior to the Chicxulub crater rim, velocities of 6000-

$3706300 \mathrm{~m} / \mathrm{s}$ are observed at depths of 6-15 km [Christeson et al., 2001], which agree well with

371 laboratory measurements of 6000-6400 m/s for granite at pressures of 2-4 kbar [Birch, 1960].

372 Morgan et al. [2016] estimate that material that formed the Chicxulub peak ring originated from

373 8- to $10-\mathrm{km}$ depth, and moved $>20 \mathrm{~km}$ during crater formation. Shock metamorphism and

374 subsequent brecciation during crater excavation and modification decrease the seismic velocity

375 and density [e.g., Walsh, 1965; Toksöz et al., 1976; Langenhorst and Deutsch, 1994]. Fractures

376 (Figure 4f), foliated shear zones, and cataclasites are observed extensively in the granitoid

377 section [Morgan et al., 2016], and the physical property data presented here suggest that highly

378 shocked and damaged lithologies are present and pervasive throughout the peak ring.

379 Although the peak ring is predominantly composed of granitoid, other lithologies are

380 observed in the $588 \mathrm{~m}$ cored section of unit 4 including cumulated thicknesses of $46 \mathrm{~m}$ of

381 suevite, $24 \mathrm{~m}$ of impact melt rock, and $15 \mathrm{~m}$ of dolerite (Figure 3). Both the suevite and impact

382 melt rock have higher velocities, and lower porosities, than observed in units 2 and 3 (Table 1).

383 The unit 4 suevite and impact melt rock have no visible carbonate (lower velocity) clasts, but

384 mafic metamorphic (higher velocity) clasts are present [Morgan et al., 2017]. Both suevite and

385 impact melt rock are pervasively altered, with the clay fraction dominated by phyllosilicates,

386 mainly mica [Morgan et al., 2017]. As for units 2 and 3, the overall low velocities and densities,

387 and high porosities, of the unit 4 suevite and impact melt rock are attributed to the alteration

388 products; the higher velocities and lower porosities compared to units 2 and 3 are likely a result

389 of compositional differences, especially the lack of carbonate clasts.

390 Within crystalline basement unit 4, the suevite and impact melt rock are associated with 391 higher porosities (15-19\%) and lower densities $\left(2.28-2.33 \mathrm{~g} / \mathrm{cm}^{3}\right)$, and the dolerite with higher

392 sample and borehole sonic velocities ( $4821 \mathrm{~m} / \mathrm{s}$ and $4265 \mathrm{~m} / \mathrm{s}$, respectively) and higher densities

$393\left(2.57-2.58 \mathrm{~g} / \mathrm{cm}^{3}\right)$ compared to the granitoid measurements (Figure 3 and Table 1). The increase

394 in porosity of the suevite and impact melt rock is important, because it implies an increase in

395 permeability especially in the region between 1251-1316 mbsf dominated by suevite and impact 
melt rock (Figure 3). In Yax-1, similar intervals were pathways for circulating hydrothermal

397 fluid [Abramov and Kring, 2007] and that may also be the case in M0077A.

398 Borehole sonic, VSP, and core determinations of P-wave velocities and densities in the 399 deformed zones of impact structures are rare [Popov et al., 2014]. One useful comparison comes 400 from drilling into the central peak of the Bosumtwi impact crater, a 10.5 km diameter, 1.07 Ma 401 old complex crater in Ghana [Scholz et al., 2002; Koeberl et al., 2007]. The Bosumtwi target 402 rocks are primarily greenschist facies metasediments; cores and geophysical logs from the $\sim 250$ $403 \mathrm{~m}$ thick interval down from the top of the central peak revealed an interleaved mixture of 404 polymict and monomict lithic breccias, impact melt-poor suevite, and blocks of target rock 405 reminiscent of Fig. 3a [Ferrière et al., 2007]. MSCL logging [Hunze and Wonik, 2007] and 406 discrete sample measurements [Elbra et al., 2007] also generally show low densities. The VSP 407 P-wave velocities increase with depth by $\sim 30 \%$ from $2.6 \mathrm{~km} / \mathrm{s}$ to $3.34 \mathrm{~km} / \mathrm{s}$ in the 200 -m-thick 408 deformed uplift zone [Schmitt et al., 2007]. These values, too, are substantially less than the $~ 5.5$

$409 \mathrm{~km} / \mathrm{s}$ expected for the undamaged target metasediments. The rapid changes in P-wave velocity 410 with depth at Bosumtwi relative to those seen at Chicxulub peak ring drilling likely originate 411 from the large differences in the dimensions and material displacement magnitudes between the 412 two structures, although the P-wave velocities reflect in part fracturing and damage within the 413 shifted target rock.

\section{5. Conclusions}

415 Chicxulub peak-ring rocks at Hole M0077A have unusual physical properties. Across the 416 boundary between post-impact sedimentary rock and suevite we measure a sharp decrease in 417 velocities and densities, and an increase in porosity. Typical suevite values are 2900-3700 m/s, $418 \quad 2.06-2.37 \mathrm{~g} / \mathrm{cm}^{3}$, and 20-35\% for velocity, density, and porosity, respectively. The suevite is also 419 associated with a low-frequency reflector package on MCS profiles and a low-velocity layer in 420 FWI images. The thin $(25 \mathrm{~m})$ impact melt rock unit has velocities of $3650-4350 \mathrm{~m} / \mathrm{s}$, densities of $4212.26-2.37 \mathrm{~g} / \mathrm{cm}^{3}$, and porosities of $19-22 \%$; density and porosity values are intermediate between 
422 the overlying suevite and underlying granitoid rocks, while the velocity values are similar to

423 those for the underlying granitic basement. The Hole M0077A impact melt rock velocities and

424 densities are considerably less than values of $5800 \mathrm{~m} / \mathrm{s}$ and $2.68 \mathrm{~g} / \mathrm{cm}^{3}$ measured at an onshore

425 well Y6 located in the annular trough. We associate the low velocity, low density, and high

426 porosity of suevite and impact melt rock with rapid emplacement, hydrothermal alteration

427 products and observations of pore space, vugs, and vesicles. Granitoid rocks have velocities of

$4284000-4200 \mathrm{~m} / \mathrm{s}$, densities of $2.39-2.44 \mathrm{~g} / \mathrm{cm}^{3}$, and porosities of $8-13 \%$; these values differ

429 significantly from typical granite which has higher velocities and densities, and porosities $<1 \%$.

430 Hole M0077A granitoid peak-ring physical property values indicate considerable fracturing, and

431 are consistent with numerical models for peak-ring formation where the lithologies present

432 within the peak ring represent the most shocked and damaged rocks in an impact basin. We map

433 thicker suevite away from the peak ring, suggesting that this unit flowed downslope from a

434 collapsing central uplift during and after peak-ring formation, accumulating preferentially within

435 the central basin. We interpret suevite below the Paleogene sediments in the annular trough, peak

436 ring, and central basin, implying that, post impact, suevite covered the entire floor of the impact

437 basin.

438

439 Acknowledgements. We thank captain and crew, drilling team, and technical staff who

440 participated in shipboard and/or shore-based operations, and Tom Hess, Steffen Saustrup, and

441 Penelope Pharr for technical support at UTIG. The European Consortium for Ocean Research

442 Drilling (ECORD) implemented Expedition 364 with funding from the International Ocean

443 Discovery Program (IODP) and the International Continental scientific Drilling Project (ICDP).

444 We thank the reviewers and editor William McKinnon for their constructive comments on an

445 earlier version of this manuscript. Data and samples can be requested from IODP. U.S.

446 participants were supported by the U.S. Science Support Program and NSF grants OCE 1737351,

447 OCE 1736826, OCE 1737087, OCE 1737037, OCE 1736951, and OCE 1737199. J.V.M was

448 funded by NERC, Grant: NE/P005217/1. This is UTIG contribution 3262. 


\section{References}

Abramov, O., and D. A. Kring (2007), Numerical modeling of impact-induced hydrothermal activity at the Chicxulub crater, Meteorit. Planet. Sci., 42, 93-112, doi: 10.1111/j.19455100.2007.tb00220.x.

Barton, P. J., R. A. F. Grieve, J. V. Morgan, A. T. Surendra, P. M. Vermeesch, G. L. Christeson, S. P. S. Gulick, and M. R. Warner (2010), Seismic images of Chicxulub impact melt sheet and comparison with the Sudbury structure, in Large Meteorite Impacts and Planetary Evolution IV, edited by R. L. Gibson and W. U. Reimold, pp. 103-113, Geol. Soc. Amer. Spec. Pap. 465, doi: 10.1130/2010.2465(07).

Birch, F. (1960), The velocity of compressional waves in rocks to 10 kilobars: 1, J. Geophys. Res., 65, 1083-1102, doi: 10.1029/JZ065i004p01083.

Bloch, S., R. H. Lander, and L. Bonnell (2002), Anomalously high porosity and permeability in deeply buried sandstone reservoirs: Origin and predictability, AAPG Bulletin, 86, 301-328.

Christeson, G. L., Y. Nakamura, R. T. Buffler, J. Morgan, and M. Warner (2001), Deep crustal

structure of the Chicxulub impact crater, J. Geophys. Res., 106, 21751-21769.

Collins, G. S., J. V. Morgan, P. J. Barton, G. L. Christeson, S. P. S. Gulick, J. UrrutiaFucugauchi, M. R. Warner, and K. Wünnemann (2008), Dynamic modeling suggests terrace

zone asymmetry in the Chicxulub crater is caused by target heterogeneity, Earth Planet. Sci. Lett., $270,221-230$.

David, C., B. Menéndez, and M. Darot (1999), Influence of stress-induced and thermal cracking on physical properties and microstructure of La Peyratte granite, International Journal of Rock Mechanics and Mining Sciences, 36, 433-448, doi: 10.1016/S0148-9062(99)00010-8. 
472 Elbra, T., A. Kontny, L. J. Pesonen, N. Schleifer, and C. Schell (2007), Petrophysical and

473 paleomagnetic data of drill cores from the Bosumtwi impact structure, Ghana, Meteorit.

$474 \quad$ Planet. Sci., 42, 829-838, doi: 10.1111/j.1945-5100.2007.tb01078.x.

475 Elbra, T., and L. J. Pesonen (2011), Physical properties of the Yaxcopoil-1 deep drill core,

476 Chicxulub impact structure, Mexico, Meteorit. Planet. Sci., 46, 1640-1652, doi:

$477 \quad$ 10.1111/j.1945-5100.2011.01253.x.

478 Ferrière, L., C. Koeberl, and U. Reimold (2007), Drill core LB- 08A, Bosumtwi impact

479 structure, Ghana: Petrographic and shock metamorphic studies of material from the central

480 uplift, Meteorit. Planet. Sci., 42, 611-633, doi: doi:10.1111/j.1945-5100.2007.tb01064.x.

481 Goto, K., R. Tada, E. Tajika, T. J. Bralower, T. Hasegawa, and T. Matsui (2004), Evidence for

482 ocean water invasion into the Chicxulub Crater at the Cretaceous/Tertiary boundary,

483 Meteorit. Planet. Sci., 39, 1233-1247.

484 Grieve, R. A. F., P. B. Robertson, and M. R. Dence (1981), Constraints on the formation of ring

485 impact structures, based on terrestrial data, Proc. Lunar Planet. Sci., 12A, 37-57.

486 Gulick, S. P. S., P. J. Barton, G. L. Christeson, J. V. Morgan, M. McDonald, K. Mendoza-

487 Cervantes, Z. F. Pearson, A. Surendra, J. Urrutia-Fucugauchi, P. M. Vermeesch, and M. R.

488 Warner (2008), Importance of pre-impact crustal structure for the asymmetry of the

489 Chicxulub impact crater, Nature Geosci., 1, 131-135, doi: 10.1038/ngeo103.

490 Gulick, S. P. S., G. L. Christeson, P. J. Barton, R. A. F. Grieve, J. V. Morgan, and J. Urrutia-

491 Fucugauchi (2013), Geophysical characterization of the Chicxulub impact crater, Rev.

492 Geophys., 51, 31-52, doi: 10.1002/rog.200007.

493 Han, D.-h., A. Nur, and D. Morgan (1986), Effects of porosity and clay content on wave

494 velocities in sandstones, Geophysics, 51, 2093-2107, doi: 10.1190/1.1442062. 
495

496

497

498

499

500

501

502

503

504

505

506

507

508

509

510

511

512

513

514

515

516

Hecht, L., A. Wittmann, R. T. Schmitt, and D. Stöffler (2004), Composition of impact melt particles and the effects of post- impact alteration in suevitic rocks at the Yaxcopoil- 1 drill core, Chicxulub crater, Mexico, Meteorit. Planet. Sci., 39, 1169-1186, doi: doi:10.1111/j.1945-5100.2004.tb01135.x.

Hildebrand, A. R., G. T. Penfield, D. A. Kring, M. Pilkington, A. Camargo, Z., S. B. Jacobsen, and W. V. Boynton (1991), Chicxulub Crater: A possible Cretaceous/Tertiary boundary impact crater on the Yucatán Peninsula, Mexico, Geology, 19, 867-871.

Hunze, S., and T. Wonik (2007), Lithological and structural characteristics of the Lake Bosumtwi impact crater, Ghana: Interpretation of acoustic televiewer images, Meteorit. Planet. Sci., 42, 779-792, doi: 10.1111/j.1945-5100.2007.tb01074.x.

Koeberl, C., B. Milkereit, J. T. Overpeck, C. A. Scholz, P. Y. O. Amoako, D. Boamah, S. K. Danuor, T. Karp, J. Kueck, R. E. Hecky, J. King, and J. A. Peck (2007), An international and multidisciplinary drilling project into a young complex impact structure: The 2004 ICDP Bosumtwi impact crater, Ghana, drilling project - An overview, Meteorit. Planet. Sci., 42, 483-511.

Kring, D. A., and W. V. Boynton (1992), Petrogenesis of an augite-bearing melt rock in the Chicxulub structure and its relationship to K/T impact spherules in Haiti, Nature, 141-144, doi: $10.1038 / 358141 \mathrm{a} 0$.

Kring, D. A., F. Hörz, L. Zurcher, and J. U. Fucugauchi (2004), Impact lithologies and their emplacement in the Chicxulub impact crater: Initial results from the Chicxulub Scientific Drilling Project, Yaxcopoil, Mexico, Meteorit. Planet. Sci., 39, 879-897, doi: 10.1111/j.1945-5100.2004.tb00936.x. 
517 Kring, D. A. (2005), Hypervelocity collisions into continental crust composed of sediments and 518 an underlying crystalline basement: comparing the Ries $(\sim 24 \mathrm{~km})$ and Chicxulub $(\sim 180 \mathrm{~km})$ 519 impact craters, Chem Erde-Geochem, 65, 1-46.

520 Langenhorst, F., and A. Deutsch (1994), Shock experiments on pre-heated $\alpha$ - and $\beta$-quartz: I. 521 Optical and density data, Earth Planet. Sci. Lett., 125, 407-420, doi: 10.1016/0012$522 \quad 821 X(94) 90229-1$.

523 Mayr, S. I., A. Wittmann, H. Burkhardt, Y. Popov, R. Romushkevich, I. Bayuk, P. Heidinger, 524 and H. Wilhelm (2008), Integrated interpretation of physical properties of rocks of the 525 borehole Yaxcopoil-1 (Chicxulub impact structure), J. Geophys. Res., 113, B07201, doi: 10.1029/2007JB005420.

Mayr, S. I., H. Burkhardt, Y. Popov, R. Romushkevich, D. Miklashevskiy, D. Gorobtsov, P. Heidinger, and H. Wilhelm (2009), Physical rock properties of the Eyreville core, Chesapeake Bay impact structure, Geological Society of America Special Papers, 458, 137163, doi: 10.1130/2009.2458(07).

Morgan, J. V., M. R. Warner, J. Brittan, R. Buffler, A. Camargo, G. Christeson, P. Denton, A. Hildebrand, R. Hobbs, H. Macintyre, G. Mackenzie, P. Maguire, Marin, Y. Nakamura, M. Pilkington, V. Sharpton, D. Snyder, G. Suarez, and A. Trejo (1997), Size and morphology of

538 Morgan, J. V., G. L. Christeson, and C. A. Zelt (2002), Testing the resolution of a 3D velocity 539 tomogram across the Chicxulub crater, Tectonophysics, 355, 215-226. 
Morgan, J. V., M. R. Warner, G. S. Collins, R. A. F. Grieve, G. L. Christeson, S. P. S. Gulick, and P. J. Barton (2011), Full waveform tomographic images of the peak ring at the Chicxulub impact crater, J. Geophys. Res., 116, B06303, doi: 10.1029/2011JB008210.

Morgan, J. V., S. P. S. Gulick, T. Bralower, E. Chenot, G. L. Christeson, P. Claeys, C. S.

544 Cockell, G. S. Collins, M. Coolen, L. Ferrière, C. Gebhardt, K. Goto, H. Jones, D. A. Kring, Perez-Cruz, A. Pickersgill, M. Pölchau, A. Rae, C. Rasmussen, M. Rebolledo-Vieyra, U. Riller, H. Sato, D. Schmitt, J. Smit, S. Tikoo-Schantz, N. Tomioka, J. Urrutia-Fucugauchi, M. T. Whalen, A. Wittmann, K. Yamaguchi, and W. Zylberman (2016), The formation of peak rings in large impact craters, Science, 354, 878-882, doi: 10.1126/science.aah6561.

Morgan, J. V., S. P. S. Gulick, C. L. Mellet, S. L. Green, and Expedition 364 Scientists (2017), Chicxulub: Drilling the K-Pg Impact Crater, Proceedings of the International Ocean Discovery Program, 364, International Ocean Discovery Program, College Station, TX, doi: 10.14379/iodp.proc.364.103.2017.

Nur, A., and G. Simmons (1969), The effect of saturation on velocity in low porosity rocks, Earth Planet. Sci. Lett., 7, 183-193, doi: 10.1016/0012-821X(69)90035-1.

Popov, Y., S. Mayr, R. Romushkevich, H. Burkhardt, and H. Wilhelm (2014), Comparison of petrophysical properties of impactites for four meteoritic impact structures, Meteorit. Planet. Sci., 49, 896-920, doi: 10.1111/maps.12299.

Schmitt, D. R., B. Milkereit, T. Karp, C. Scholz, S. Danuor, D. Meillieux, and M. Welz (2007), In situ seismic measurements in borehole LB-08A in the Bosumtwi impact structure, Ghana: Preliminary interpretation, Meteorit. Planet. Sci., 42, 755-768, doi: 10.1111/j.19455100.2007.tb01072.x. 
Schmitt, D. R. (2015), 11.03 - Geophysical Properties of the Near Surface Earth: Seismic

564 Properties, in Treatise on Geophysics (Second Edition), edited by G. Schubert, pp. 43-87,

565 Elsevier, Oxford, doi: 10.1016/B978-0-444-53802-4.00190-1.

566 Scholz, C. A., T. Karp, K. M. Brooks, B. Milkereit, P. Y. O. Amoako, and J. A. Arko (2002),

567 Pronounced central uplift identified in the Bosumtwi impact structure, Ghana, using

568 multichannel seismic reflection data, Geology, 30, 939-942.

569 Schuraytz, B. C., V. L. Sharpton, and L. E. Marín (1994), Petrology of impact-melt rocks at the

570 Chicxulub multiring basin, Yucatán, Mexico, Geology, 22, 868-872.

571 Sharpton, V. L., G. B. Dalyrymple, L. E. Marin, G. Ryder, B. C. Schuraytz, and J. Urrutia-

$572 \quad$ Fucugauchi (1992), New links between the Chicxulub impact structure and the

573 Cretaceous/Tertiary boundary, Nature, 359, 819-821.

574 Sharpton, V. L., L. E. Marín, C. Carney, S. Lee, G. Ryder, B. C. Schuraytz, P. Sikora, and P. D.

575 Spudis (1996), A model of the Chicxulub impact basin based on evaluation of geophysical

576 data, well logs, and drill core samples, in The Cretaceous-Tertiary event and other

577 catastrophes in Earth history, vol. Geol. Soc. Am., Spec. Pap. 307, edited by G. Ryder, D.

$578 \quad$ Fastovsky and S. Gartner, pp. 55-74.

579 Stöffler, D., N. A. Artemieva, B. A. Ivanov, L. Hecht, T. Kenkmann, R. T. Schmitt, R. A. Tagle,

580 and A. Wittmann (2004), Origin and emplacement of the impact formation at Chicxulub,

581 Mexico, as revealed by the ICDP deep drilling at Yaxcopoil-1 and by numerical modeling,

$582 \quad$ Meteorit. Planet. Sci., 39, 1035-1067.

583 Stöffler, D., and R. A. F. Grieve (2007), Impactites, in Metamorphic Rocks: A Classification and

584 Glossary of Terms, edited by D. Fettes and J. Desmons, pp. 82-92, Cambridge University

585 Press, Cambridge, UK. 
Toksöz, M., C. Cheng, and A. Timur (1976), Velocities of seismic waves in porous rocks,

587 Geophysics, 41, 621-645, doi: 10.1190/1.1440639.

588 Vermeesch, P. M., and J. V. Morgan (2004), Chicxulub central crater structure: Initial results

589 from physical property measurements and combined velocity and gravity modeling, Meteorit.

$590 \quad$ Planet. Sci., 39, 1019-1034.

591 Vermeesch, P. M. (2006), Geophysical modelling of the Chicxulub crater, Ph.D. thesis, 418 pp, 592 Imperial College, London.

593 Virieux, J., and S. Operto (2009), An overview of full-waveform inversion in exploration

594 geophysics, Geophysics, 74, WCC1-26, doi: 10.1190/1.3238367.

595 Walsh, J. B. (1965), The effect of cracks on the compressibility of rock, J. Geophys. Res., 70,

596 381-389, doi: 10.1029/JZ070i002p00381.

597 Ward, W. C., G. Keller, W. Stinnesbeck, and T. Adatte (1995), Yucatán subsurface stratigraphy:

598 Implications and constraints for the Chicxulub impact, Geology, 23, 873-876.

599 Wittmann, A., T. Kenkmann, L. Hecht, and D. Stöffler (2007), Reconstruction of the Chicxulub

600 ejecta plume from its deposits in drill core Yaxcopoil-1, Geol. Soc. Am. Bull., 119, 1151-

$601 \quad$ 1167, doi: 10.1130/B26116.1.

602 Yilmaz, O. (1987), Seismic Data Processing, 526 pp., Society of Exploration Geophysics, Tulsa, $603 \quad$ OK.

604 Zürcher, L., and D. A. Kring (2004), Hydrothermal alteration in the core of the Yaxcopoil-1

605 borehole, Chicxulub impact structure, Mexico, Meteorit. Planet. Sci., 39, 1199-1221, doi:

$606 \quad 10.1111 / \mathrm{j} .1945-5100.2004 . t b 01137 . x$.

607

608 
Table 1. Average Physical Property Values and Standard Deviation

\begin{tabular}{|c|c|c|c|c|c|c|c|c|}
\hline Subunit & $\begin{array}{l}\text { Top } \\
\text { Depth } \\
\text { (mbsf) }\end{array}$ & Dominant Lithology & $\begin{array}{l}\text { Sample } \\
\text { Velocity } \\
(\mathrm{m} / \mathrm{s})\end{array}$ & $\begin{array}{l}\text { Sonic } \\
\text { Velocity } \\
(\mathrm{m} / \mathrm{s})\end{array}$ & $\begin{array}{l}\text { VSP } \\
\text { Velocity } \\
(\mathrm{m} / \mathrm{s})\end{array}$ & $\begin{array}{l}\text { Sample } \\
\text { Porosity } \\
(\%)\end{array}$ & $\begin{array}{l}\text { Sample } \\
\text { Density } \\
\left(\mathrm{g} / \mathrm{cm}^{3}\right)\end{array}$ & $\begin{array}{l}\text { MSCL } \\
\text { Density } \\
\left(\mathrm{g} / \mathrm{cm}^{3}\right)\end{array}$ \\
\hline $1 \mathrm{~A}$ & 505.70 & marlstone & $3147 \pm 501$ & $2574 \pm 220$ & $2619 \pm 33$ & $28 \pm 7$ & $2.02 \pm 0.08$ & $1.99 \pm 0.12$ \\
\hline 1B & 530.18 & marlstone limestone & $2984 \pm 204$ & $2728 \pm 211$ & $2642 \pm 5$ & $29 \pm 5$ & $1.96 \pm 0.11$ & $2.07 \pm 0.13$ \\
\hline $1 \mathrm{C}$ & 537.80 & marlstone limestone & $3163 \pm 404$ & $2680 \pm 182$ & $2613 \pm 27$ & $28 \pm 5$ & $2.05 \pm 0.08$ & $2.10 \pm 0.13$ \\
\hline 1D & 559.75 & marlstone limestone & $3101 \pm 305$ & $2642 \pm 247$ & $2614 \pm 62$ & $26 \pm 5$ & $2.04 \pm 0.13$ & $2.06 \pm 0.18$ \\
\hline $1 \mathrm{E}$ & 580.89 & limestone & $3769 \pm 392$ & $3159 \pm 336$ & $3040 \pm 144$ & $21 \pm 7$ & $2.28 \pm 0.15$ & $2.32 \pm 0.16$ \\
\hline $1 \mathrm{~F}$ & 607.27 & limestone & $3018 \pm 243$ & $3401 \pm 300$ & $3082 \pm 70$ & $14 \pm 2$ & $2.47 \pm 0.03$ & $2.37 \pm 0.16$ \\
\hline $1 \mathrm{G}$ & 616.58 & mud-wackestone & & $3703 \pm 107$ & & & & $2.53 \pm 0.06$ \\
\hline $2 \mathrm{~A}$ & 617.33 & suevite & $3106 \pm 126$ & $2921 \pm 91$ & $2873 \pm 77$ & $35 \pm 2$ & $2.06 \pm 0.03$ & $2.09 \pm 0.07$ \\
\hline 2B & 664.52 & suevite & $3396 \pm 431$ & $3100 \pm 255$ & $3187 \pm 199$ & $29 \pm 7$ & $2.18 \pm 0.13$ & $2.17 \pm 0.15$ \\
\hline $2 \mathrm{C}$ & 712.84 & suevite & $3635 \pm 250$ & $3635 \pm 116$ & $3689 \pm 25$ & $20 \pm 4$ & $2.36 \pm 0.08$ & $2.37 \pm 0.16$ \\
\hline $3 \mathrm{~A}$ & 721.61 & impact melt rock & $4361 \pm 361$ & $3878 \pm 186$ & $3793 \pm 41$ & $19 \pm 3$ & $2.37 \pm 0.05$ & $2.36 \pm 0.16$ \\
\hline $3 B$ & 737.56 & impact melt rock & $3829 \pm 679$ & $3636 \pm 188$ & $3898 \pm 24$ & $22 \pm 4$ & $2.29 \pm 0.05$ & $2.26 \pm 0.10$ \\
\hline 4 & 747.02 & granitoid & $4171 \pm 569$ & $4014 \pm 277$ & $4225 \pm 134$ & $11 \pm 4$ & $2.44 \pm 0.07$ & $2.39 \pm 0.12$ \\
\hline $4^{*}$ & $*$ & suevite & $4165 \pm 472$ & $3967 \pm 308$ & $4103 \pm 6$ & $19 \pm 6$ & $2.33 \pm 0.09$ & $2.30 \pm 0.12$ \\
\hline $4^{*}$ & $*$ & impact melt rock & $4487 \pm 550$ & $4014 \pm 356$ & $4096 \pm 26$ & $15 \pm 5$ & $2.33 \pm 0.05$ & $2.28 \pm 0.15$ \\
\hline $4^{*}$ & $*$ & granitoid & $4139 \pm 569$ & $4006 \pm 262$ & $4227 \pm 133$ & $10 \pm 3$ & $2.46 \pm 0.05$ & $2.40 \pm 0.10$ \\
\hline $4^{*}$ & $*$ & dolerite & $4821 \pm 335$ & $4265 \pm 276$ & $4237 \pm 130$ & $10 \pm 3$ & $2.57 \pm 0.07$ & $2.58 \pm 0.22$ \\
\hline
\end{tabular}

*Unit 4 was not divided into subunits; these values are calculated for depths within Unit 4 where core description identified the dominant lithology. 


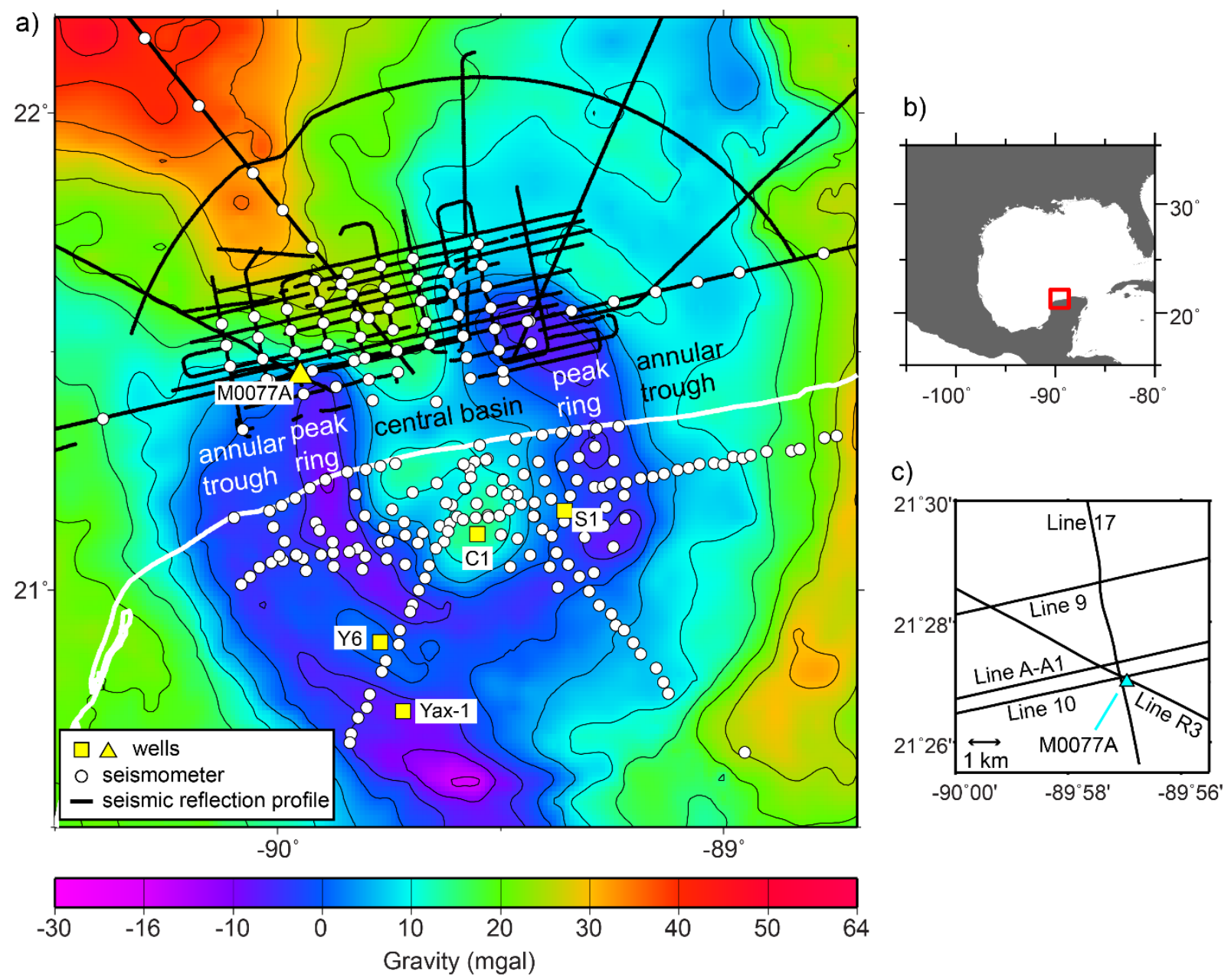

Figure 1. a) Bouguer gravity anomaly map (gravity data courtesy of A. Hildebrand and M. Pilkington) over the Chicxulub impact crater. The coastline is displayed with the white line. b) Regional setting, with red rectangle outline the region shown in panel a. c) Close-up of Hole M0077A location showing position of well with respect to seismic profiles. At the closest position to Hole M0077A, Line R3 is $69 \mathrm{~m}$ north-northeast, Line 10 is $151 \mathrm{~m}$ north, and Line $17 \mathrm{~b}$ is $161 \mathrm{~m}$ west. 
a) Annular Trough Peak Ring
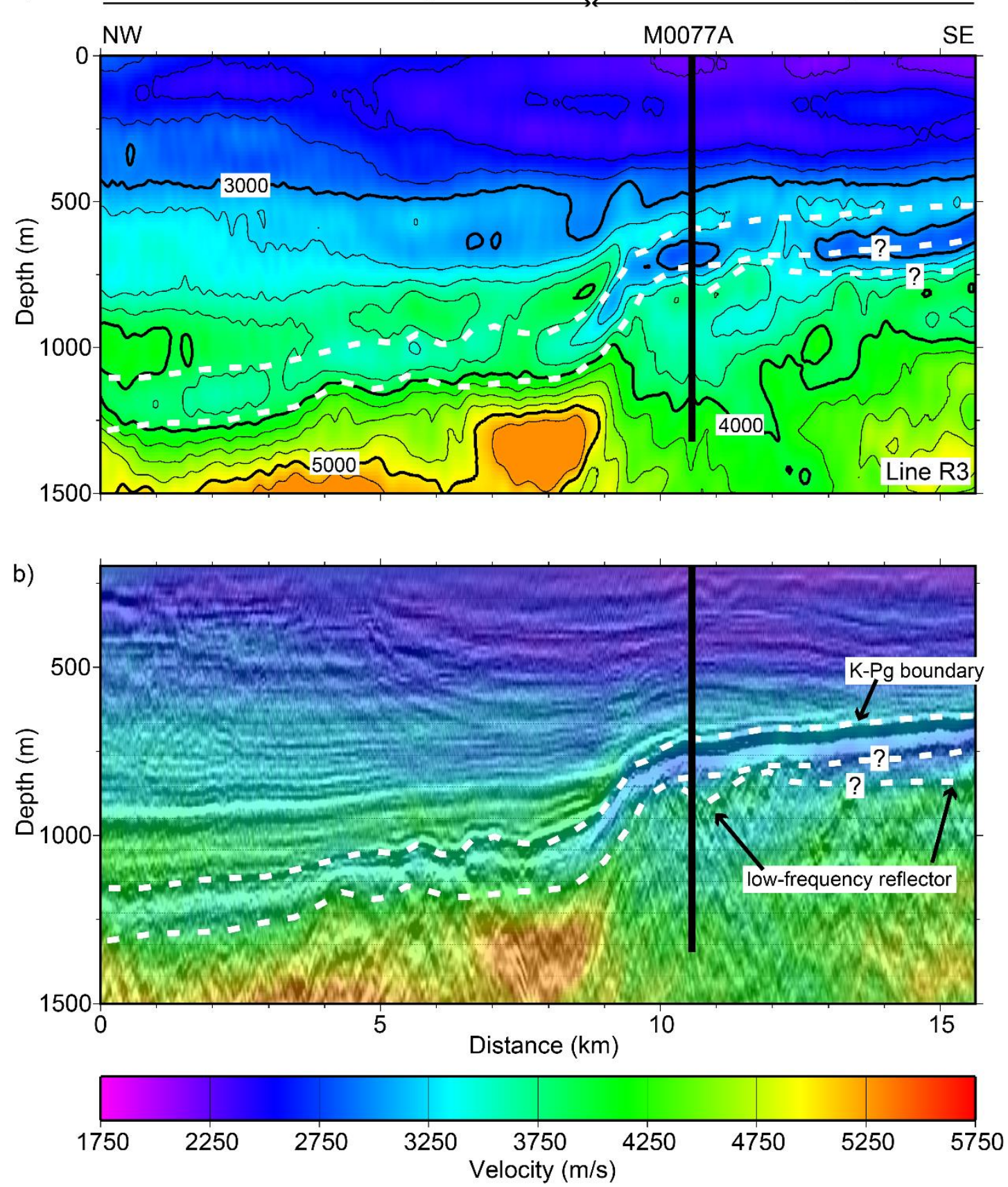

Figure 2. Full wavefield inverted velocity model for Line R3 [Morgan et al., 2011]: a) Plotted with a contour interval $250 \mathrm{~m} / \mathrm{s}$; b) Overlain on seismic Line R3, with seismic data converted to depth using the same velocity model. White dashed lines mark top and base of low-velocity layer as guided by seismic reflectors; two possible interpretations are shown for base of low-velocity layer within the peak ring. 


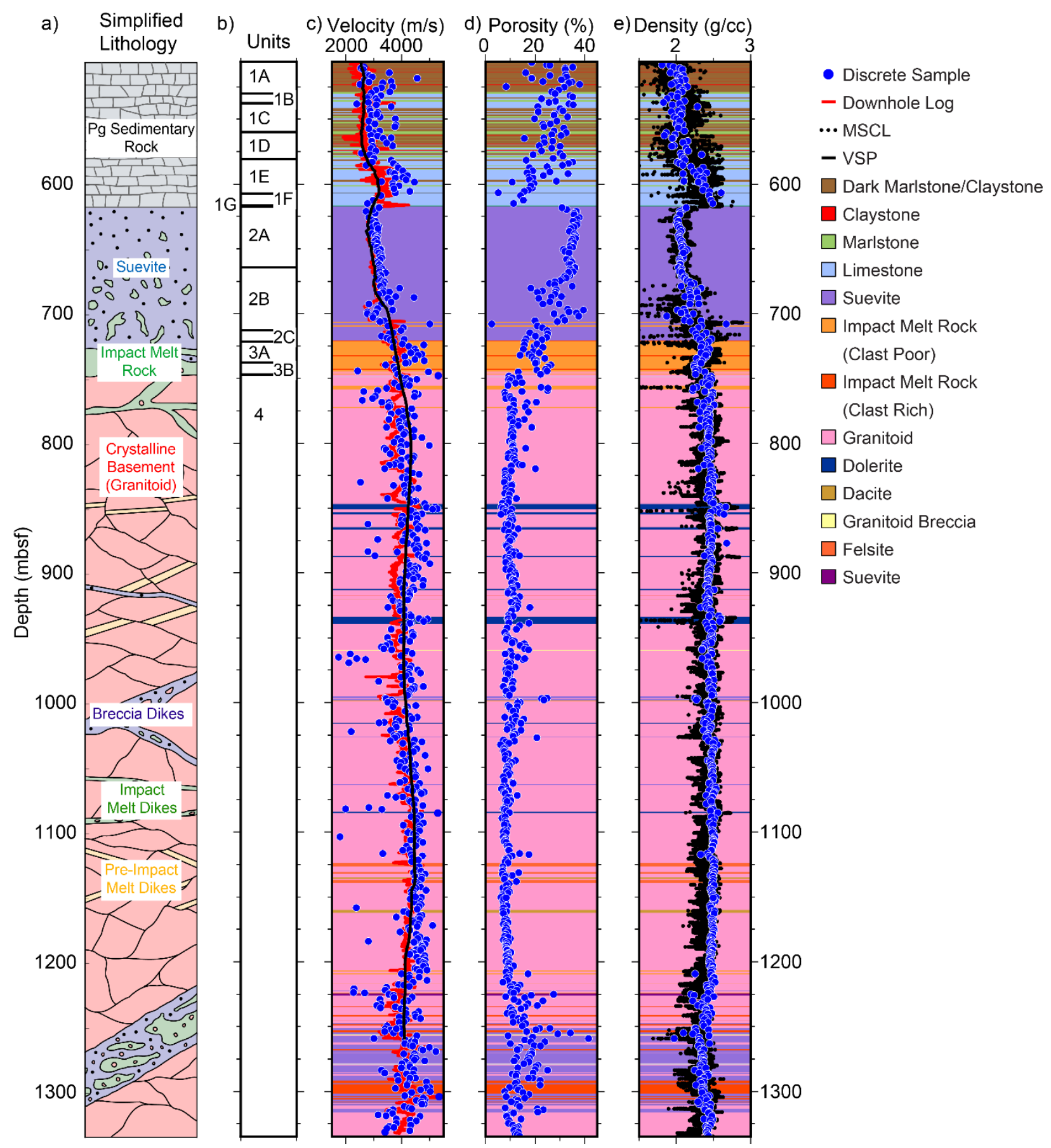

Figure 3. Hole M0077A a) Simplified lithology [Morgan et al., 2016]. b) Lithologic unit boundaries [Morgan et al., 2017]. c) P-wave velocity measurements from discrete samples, downhole logging, and vertical seismic profiles (VSP). d) Porosity measurements from discrete samples. e) Bulk density measurements from discrete samples and multi-sensor core logger (MSCL). Detailed lithology plotted as background colors in panels c-e are from Morgan et al. [2017]. 


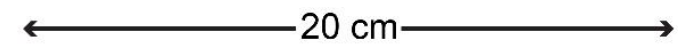

a)

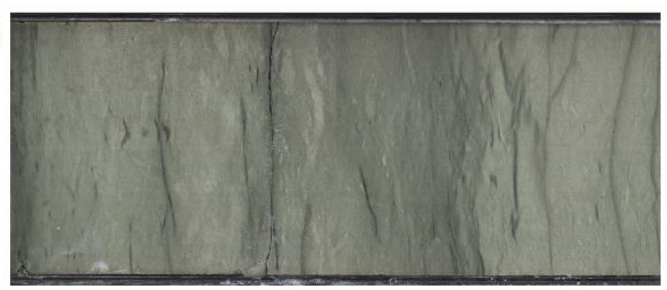

Unit 1F

Limestone

$\sim 615$ mbsf

Core 39R-2

b)

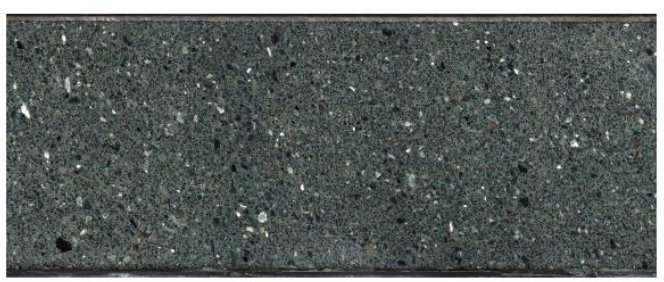

Unit 2A

Suevite

$\sim 638 \mathrm{mbsf}$

Core 47R-1

c)

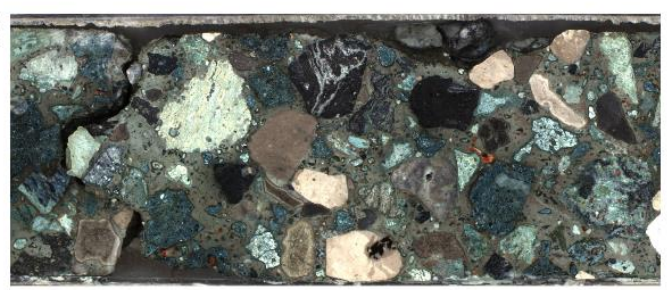

Unit 2B

Suevite

$\sim 688 \mathrm{mbsf}$

Core 65R-1

d)

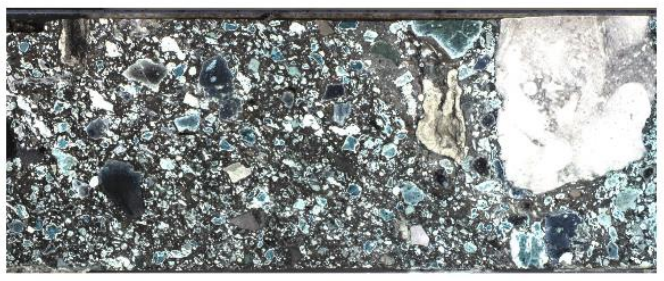

Unit 2C

Suevite

$\sim 714$ mbsf

Core 84R-2

e)

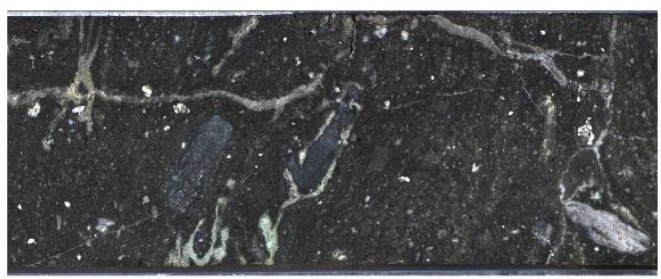

Unit 3A

Impact Melt Rock

$\sim 734$ mbsf

Core 91R-3

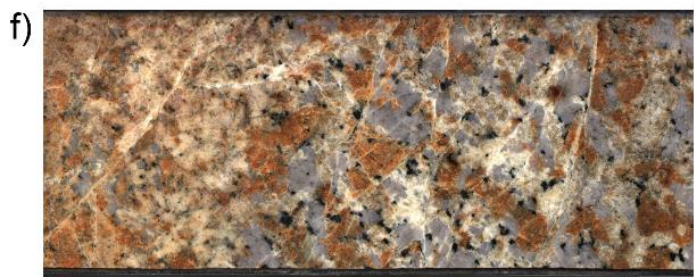

Unit 4

Fractured Granitoid

$\sim 753 \mathrm{mbsf}$

Core 98R-1

Figure 4. Digital line-scan images of the split cores displaying representative limestone, suevite, impact melt rock, and fractured granitoid. 

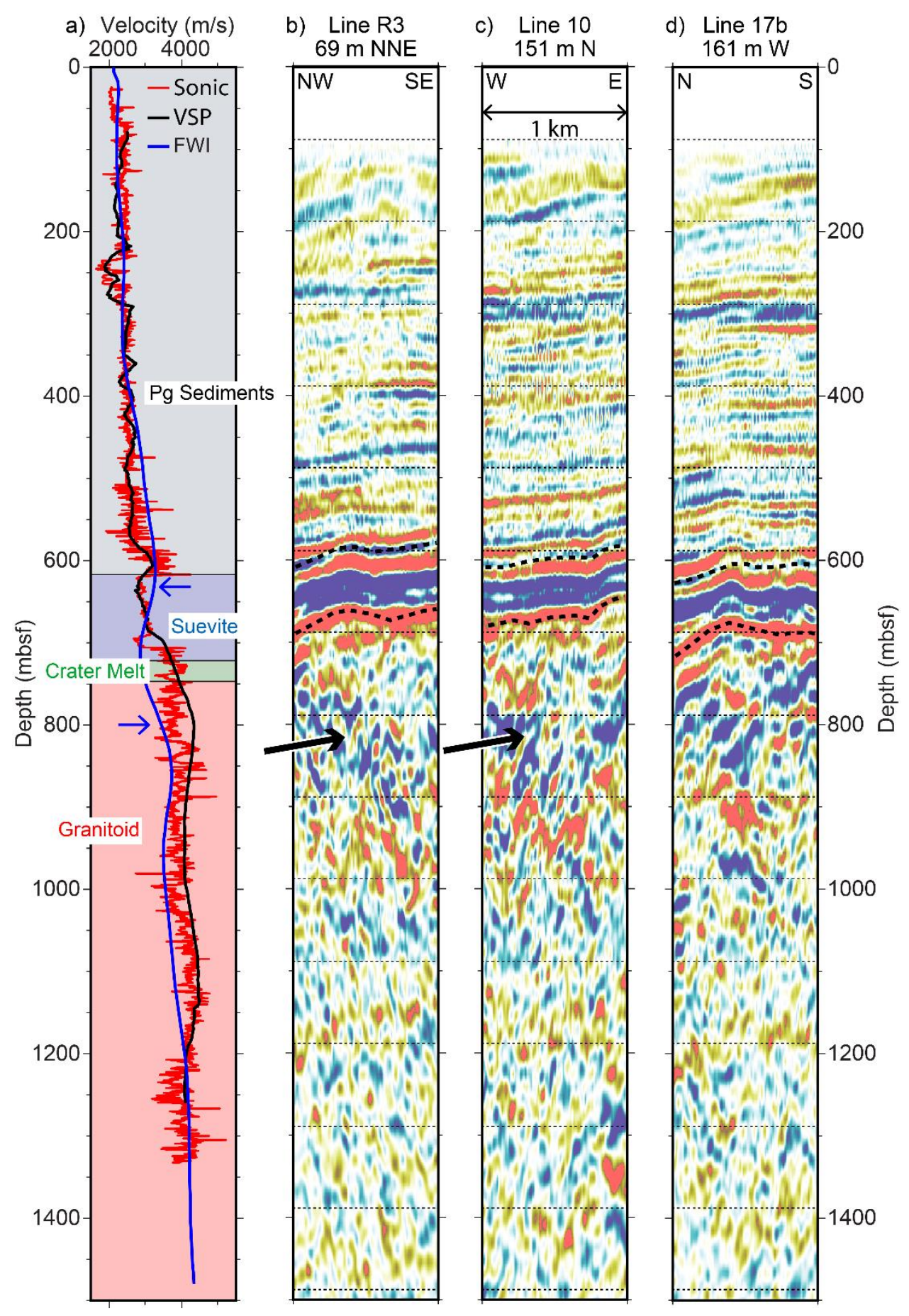

Figure 5. a) Comparison of P-wave velocity functions at Hole M0077A. Sonic and VSP are from downhole measurements. FWI is full wavefield inversion for Line R3 [Morgan et al., 2011] shifted from the sea surface to the seafloor at $19.8 \mathrm{~m}$ depth; blue arrows point to top and base of a low-velocity zone. Background colors display simplified lithology. b) Line R3, c) Line 10, d) Line 17b seismic images, converted to depth using the 1D Hole M0077A VSP velocity profile, centered at the position closest to Hole M0077A, and shifted $13.3 \mathrm{~m}$ to account for water column between source and receivers and seafloor. Locations of the seismic profiles with respect to Hole M0077A are displayed in Figure 1c. Dashed black line shows the interpreted top and base of the suevite unit as mapped in Figure 6, and black arrows point to intermittent low-frequency reflector correlated with the base of the FWI low-velocity layer. 

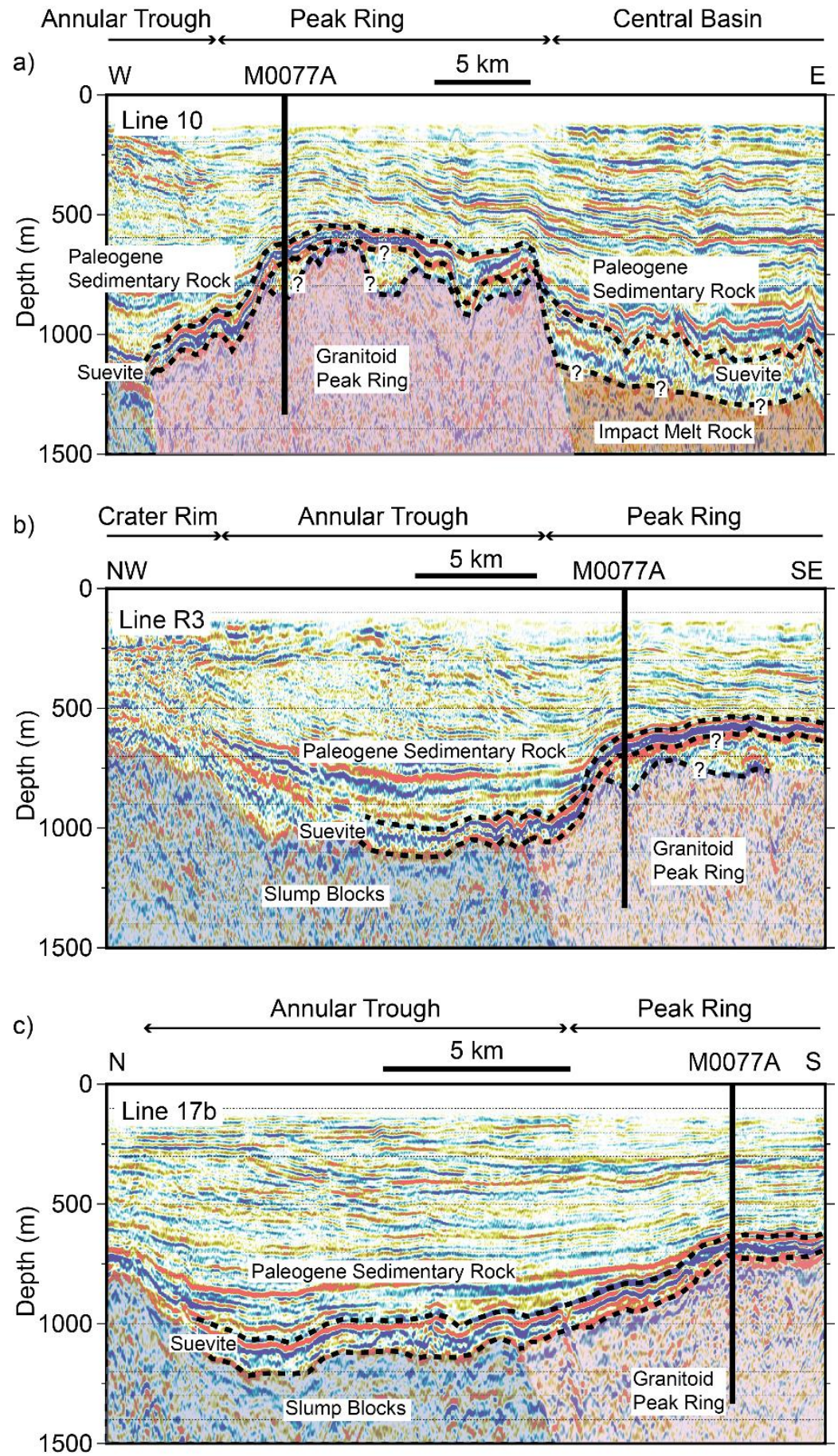

Figure 6. Seismic reflection profiles converted to depth using the 1D Hole M0077A VSP velocity profile. Upper dashed line is the interpreted base of the post-impact section, and thus the equivalent of the crater floor postimpact. The lower dashed line is the base of the suevite, with two possible interpretations on the peak ring. Blue shading are slump blocks, pink shading are granitoids of peak ring capped by impact melt rock, and orange shading is potential area of thickened impact melt rock beneath the central basin. a) Line 10; vertical exaggeration (V.E.) 12.5:1. b) Line R3; V.E. 10:1. c) Line 17b; V.E. 6.5:1. Locations of the seismic profiles with respect to Hole M0077A are displayed in Figure 1c. 
